\title{
Anti-Candida activity of a novel killer toxin from the yeast Williopsis mrakii
}

\author{
Valerie J. Hodgson, David Button and Graeme M. Walker \\ Author for correspondence: Graeme M. Walker. Tel: +441382 308000. Fax: +44 1382308663.
}

Department of Molecular and Life Sciences, University of Abertay Dundee, Bell Street, Dundee DD1 1HG, UK

\begin{abstract}
A screening of putative killer yeast strains showed that spore-forming ascomycetous yeasts of the genera Pichia and Williopsis displayed the broadest range of activity against sensitive strains of Candida spp. and Saccharomyces cerevisiae. Williopsis mrakii (NCYC 500) showed extensive antiCandida activity against strains isolated from clinical specimens. $W$. mrakii killer factor was produced in minimal media as a function of growth and its activity reached constant levels as cells entered stationary phase. The proteinaceous killer toxin was found to be unstable outwith a specific range of temperature and $\mathrm{pH}$ (above $30^{\circ} \mathrm{C}$ and $\mathrm{pH}$ 4.0), and further analysis showed that the active toxin molecule was an acidic polypeptide with a relative molecular mass between $1.8-5.0 \mathrm{kDa}$. At critical concentrations the killer factor exerted a greater effect on stationary phase cells of Candida than cells from an exponential phase of growth. At low concentrations, the killer toxin produced a fungistatic effect on sensitive yeasts but at higher concentrations there was evidence to suggest that membrane damage accounted for the zymocidal effects of the killer factor. The cidal nature of the toxin was reflected in a rapid decrease in sensitive cell viability. Findings presented suggest that $\boldsymbol{W}$. mrakii killer toxin has potential as a novel antimycotic agent in combatting medically important strains of Candida.
\end{abstract}

Keywords: Williopsis mrakii, Candida spp., yeast killer toxin, antifungal activity

\section{INTRODUCTION}

'Killer' character was first observed in laboratory strains of Saccharomyces cerevisiae by Makower \& Bevan (1963), who defined the yeast phenotypes: killer, sensitive and neutral. Killer yeasts are yeasts which secrete proteinaceous toxins which are lethal to sensitive strains but to which the killers themselves are immune (Woods \& Bevan, 1968; Bussey, 1972). There is a high frequency of killer yeasts found in laboratory stocks and collections of commercial strains (Naumova \& Naumov, 1973; Philliskirk \& Young, 1975), but the frequency is higher still in natural habitats (Stumm et al., 1977; Starmer et al., 1987).

To date, killer yeasts have been reported in several genera but the most widely studied killer systems are those of $S$. cerevisiae and Kluyveromyces lactis, whose toxins are RNA and DNA plasmid-encoded, respectively (Bussey, 1991; Stark et al., 1990). There is no evidence as yet that killer character expressed by strains of Williopsis, Pichia, Candida, Debaryomyces, Cryptococcus and Torulopsis is dependent on plasmid-encoded systems (Young \& Yagui, 1978). The genetic basis for killer character in these yeasts is, therefore, thought to be chromosomally inherited (e.g. Ashida et al., 1983).

A study of the mechanisms which govern the processing and secretion of yeast killer toxins and their binding and activity against sensitive cells could aid understanding of biosynthesis and secretory processes of hormones and neuropeptides in animals (Chan et al., 1979; Sossin et al., 1989). The killer plasmid systems of yeasts such as $S$. cerevisiae and $K$. lactis also have the potential to be used as cloning vectors for directing the secretion of expressed foreign polypeptides (Meinhardt et al., 1990; Dignard et al., 1991). Furthermore, there is considerable evidence for the killer phenomenon to be exploited in environmental biocontrol (Walker et al., 1995), in the fermentation industries (Young, 1982; Bortol et al., 1986; Boone et al., 1990) and possibly in medicine (Morace et al., 1984; Polonelli et al., 1986). With regard to clinical applications, growth inhibition produced in sensitive strains by killer yeasts and their toxins has been proposed as a means of biotyping pathogenic Candida and Cryptococcus strains (Morace et al., 1984), unrelated eukaryotes (Polonelli \& Morace, 1986) and bacterial isolates (Morace et al., 1989), 
to provide valuable epidemiological information concerning microbial infections in patients. Polonelli et al. (1989) found quantitative differences in the sensitivity of both the yeast and mycelial form of the dimorphic fungus Sporotbrix schenkii to a yeast killer toxin. Theoretically, this makes possible a therapeutic approach involving killer toxins or their derivatives in the treatment of systemic mycoses in which both yeast and mycelial morphologies of a fungal pathogen may be found. Although $\mathrm{pH}$ and temperature liability may render some yeast toxins unsuitable for administration orally or by injection (Kandel, 1988), topical applications in the treatment of superficial lesions may be possible (Polonelli et al., 1986). The findings reported in this communication indicate the potential of the killer yeast Williopsis mrakii and its toxin for use as a novel antifungal agent against an opportunistic human pathogen, the dimorphic yeast Candida albicans.

\section{METHODS}

Organisms, growth media and culture conditions. Yeast strains were obtained from the National Collection of Yeast Cultures (NCYC, Norwich, England). W. mrakii LKB169 was kindly donated by Dr Kodama (Laboratory of Kodama Brewing, Japan) and S. cerevisiae strains K-28 and S-381 by Dr Pfeiffer (Institut für Mikrobiologie und Wienforschung, Germany). The sensitive strains of Candida albicans, 2005E, C316 and 2402E, were received from Glaxo Group Research (Middlesex, England, UK) and the clinical isolates of Candida from Ninewells Hospital Medical School, (Dundee, Scotland, UK). All yeasts were inoculated and subcultured monthly on Sabouraud dextrose agar (SDA) slopes at $25^{\circ} \mathrm{C}$ for $48 \mathrm{~h}$ and then maintained at $4{ }^{\circ} \mathrm{C}$ until required. The sensitive strains were grown in Sabouraud liquid medium (SLM) and the killer strain W. mrakii NCYC 500 (designated K-500) was routinely cultured in a minimal medium, YNBGS, comprising $0.67 \%$ yeast nitrogen base without amino acids (Difco), $2 \%(\mathrm{w} / \mathrm{v}$ ) glucose (Ashida et al., 1983) supplemented with $0.5 \%\left(\mathrm{NH}_{4}\right)_{2} \mathrm{SO}_{4}$ and $0.25 \% \mathrm{MgSO}_{4} \cdot 7 \mathrm{H}_{2} \mathrm{O}$ (Hodgson, 1993). Media development studies also involved the growth of K-500 in a complex medium comprising $1 \%(\mathrm{w} / \mathrm{v})$ yeast extract, $2 \%(\mathrm{w} / \mathrm{v})$ mycological peptone and $2 \%(\mathrm{w} / \mathrm{v})$ glucose (YEPD), and in a synthetic medium, $0.3 \%$ SLM. Cultures were incubated under static conditions at $25^{\circ} \mathrm{C}$.

Identification of clinical yeasts. Microring YT (Medical Wire and Equipment), an in vitro diagnostic system, was used to identify the clinical yeast isolates. Each microring device was impregnated with a range of antimicrobial agents and dyes. A single colony of each isolate was removed using a sterile swab and plated on fresh SDA. A microring was placed in the centre of the plate and incubated at $37^{\circ} \mathrm{C}$ for $24 \mathrm{~h}$ and the response and zone sizes recorded. The results allowed a six-digit code to be assigned to each isolate and these were compared to the profiles of known yeasts.

Preparation of K-500 killer toxin. Overnight seed cultures of $\mathrm{K}-500$ ( $W$. mrakii NCYC 500) were grown in YNBGS medium at $25^{\circ} \mathrm{C}$ without shaking. A $10 \%(\mathrm{v} / \mathrm{v})$ inoculum was used to initiate fermentations in 21 pot fermenters (Electrolab) which were maintained at $25^{\circ} \mathrm{C}$ and agitated at 100 r.p.m., without aeration, for $48 \mathrm{~h}$. After centrifugation ( $2750 \mathrm{~g}$ for $10 \mathrm{~min}$ ) culture supernatants were filtered through cellulose acetate membranes (Whatman) with $0.45 \mu \mathrm{m}$ pore diameters. The clarified extracts, or crude toxin preparations, were freeze-dried and concentrated by reconstitution in a reduced volume of sterile YNBGS or distilled water.

\section{Assessment of killer toxin activity}

Streak-plate agar diffusion bioassay. A modification of the streak-plate assay of Stumm et al. (1977) was developed to screen for killer yeast activity. Methylene blue agar (MBA) was prepared in citrate/phosphate buffer, $\mathrm{pH} 4.5$, by the addition of $2 \%(\mathrm{w} / \mathrm{v}$ ) bacteriological agar, $2 \%(\mathrm{v} / \mathrm{v})$ SLM and $1 \%(\mathrm{w} / \mathrm{v})$ tryptone. The mixture was heated to $100{ }^{\circ} \mathrm{C}$ prior to the addition of $0.003 \%$ methylene blue and $5 \%(\mathrm{v} / \mathrm{v})$ glycerol. Aliquots $(15 \mathrm{ml})$ were cooled to $45^{\circ} \mathrm{C}$ prior to inoculation with the sensitive yeast at a density of $5 \times 10^{4}$ cells $\mathrm{ml}^{-1}$ and plates were poured. A single colony of the presumptive killer was streaked on the agar surface and the plates incubated at $25^{\circ} \mathrm{C}$ for $2-3 \mathrm{~d}$. The sensitive strain grew as a background lawn and killer activity was evident as a zone of clearing surrounding the streak, which was marked by dead blue-stained colonies. Toxin activity was scored using an arbitrary visual system.

Agar diffusion well bioassay. Toxin preparations were assayed according to the method of Somers \& Bevan (1969). Wells were cut in seeded MBA using a sterile borer $(5 \mathrm{~mm}$ diameter) and agar plugs removed with a sterile scalpel. Toxin samples $(50 \mu \mathrm{l})$ were pipetted into the wells and the plates incubated at $25^{\circ} \mathrm{C}$ for $2-3 \mathrm{~d}$. Subsequent zones of inhibition produced around the wells were measured to an accuracy of $1.0 \mathrm{~mm}$. The killing activity of each sample was measured and defined as the mean zone of inhibition of replicate wells.

Microtitre plate assay. Aliquots $(100 \mu \mathrm{l})$ of SLM, seeded with $1 \times 10^{5}$ cells ml $\mathrm{ml}^{-1}$ of the sensitive strain, were pipetted into microtitre wells and $100 \mu$ l control solution, or the appropriate dilution of toxin, was added and mixed using the pipette tip. The wells were incubated at $30^{\circ} \mathrm{C}$ for $18-20 \mathrm{~h}$ after which the $\mathrm{OD}_{450}$ was measured using an automatic plate reader (Titertek Multi-Scanner, Flow Laboratories). Toxin activity was expressed as the percentage reduction in growth of the sensitive strain with respect to a toxin-free control.

Membrane damage assay. A sensitive strain of C. albicans (2005E) was grown overnight at $30^{\circ} \mathrm{C}$ in $50 \mathrm{ml}$ glucose nutrient broth (GNB), comprising $2 \%(\mathrm{w} / \mathrm{v})$ glucose and $1.3 \%(\mathrm{w} / \mathrm{v})$ nutrient broth. A $3 \mathrm{ml}$ sample of cells was transferred to $50 \mathrm{ml}$ fresh GNB and incubated, with shaking, at $30^{\circ} \mathrm{C}$ until midexponential phase was reached. Cells were harvested by centrifugation ( $2750 \mathrm{~g}$ for $2 \mathrm{~min}$ ) and washed with $10 \mathrm{ml}$ buffer $\mathrm{S}$, comprising $100 \mathrm{mM}$ sodium phosphate and $2 \%$ glucose, $\mathrm{pH} 6.0$. The pellet was resuspended in $5 \mathrm{ml}$ buffer $\mathrm{S}$ and the suspension was incubated at $30^{\circ} \mathrm{C}$ for $30 \mathrm{~min}$ prior to addition of $100 \mu \mathrm{l} 2$-amino $\left[{ }^{14} \mathrm{C}\right]$ isobutyric acid (Sigma). After a further incubation of $30 \mathrm{~min}$ the cells were harvested ( $2750 \mathrm{~g}$ for $1 \mathrm{~min}$ ), washed twice in buffer $S$ containing $5 \mathrm{mg}$ sodium azide $\mathrm{ml}^{-1}$ and resuspended in $5 \mathrm{ml}$ of the same buffer. The cell suspension $(25 \mu \mathrm{l})$ was added to microtitre wells with $100 \mu \mathrm{l}$ toxin, or control solution. The plate was incubated for $60 \mathrm{~min}$ at $30^{\circ} \mathrm{C}$ in a Dynatech shaker before cells were harvested onto filter mats (Skatron Instruments) using a Skatron harvester (Model 11055 Micro96) and counted on a betaplate 1205 scintillation counter. Toxin activity was expressed as the percentage membrane damage produced in the sensitive strain according to the following equation:

membrane damage $(\%)=100-$ sample count/control count $\times 100 \%$

Temperature stability of K-500 killer toxin. Samples of killer toxin (concentrated 20 -fold) were incubated at a range of temperatures: $4,18,25,30,37,50,70$ and $100^{\circ} \mathrm{C}$. At specific intervals aliquots $(100 \mu \mathrm{l})$ were removed and assayed for toxin 
activity against a sensitive strain, Candida glabrata (NCYC 388, designated S-388), using a microtitre plate assay.

pH stability of K-500 killer toxin. Concentrated toxin was diluted in $0.1 \mathrm{M}$ citrate/phosphate buffer at a range of $\mathrm{pH}$ values with the resultant $\mathrm{pH}$ measured using a micro-electrode $(\mathrm{BDH}$ glass + electrode). 'The solutions were incubated at $18^{\circ} \mathrm{C}$ for a period of $18 \mathrm{~h}$ and the toxin activity remaining was measured against S-388 using a microtitre plate assay. The percentage reduction in growth of the indicator strain was assessed in each case with respect to toxin-free buffer controls of equivalent $\mathrm{pH}$.

Analysis of K-500 killer toxin using gel-filtration chromatography. A G-25 Sephadex column (700 ml bed volume) was washed and equilibrated with distilled water for $1 \mathrm{~h}$. Freezedried culture supernatants were reconstituted at a concentration of $276 \mathrm{mg} \mathrm{ml}^{-1}$ in distilled water and filter sterilized through $0.22 \mu \mathrm{m}$ pore-size syringe filters. Samples $(10 \mathrm{ml})$ of the filtrate were added to the column, which was eluted with distilled water and the protein profile of the eluted fractions $(5 \mathrm{ml})$ measured at $280 \mathrm{~nm}$. Toxin activity was measured against the indicator strain S-388 using a microtitre plate assay.

Effect of K-500 killer toxin on growth kinetics in sensitive yeast. The effect of crude (unconcentrated) culture supernatants on the growth profiles of three strains of C. albicans, 2005E, C316 and 2402E, was recorded. Increasing volumes of toxin $(10-100 \mu \mathrm{l})$ were made up to $100 \mu \mathrm{l}$ with sterile distilled water and added to an equal volume of SLM seeded with $1 \times 10^{5}$ cells $\mathrm{ml}^{-1}$ of the sensitive strains in the wells of a microtitre plate. The plate was placed in an automatic spectrophotometer which monitored the cell growth $(450 \mathrm{~nm})$ in each well at $15 \mathrm{~min}$ intervals over a $24 \mathrm{~h}$ period. The plate was mixed prior to growth measurements. Information was collated in situ to produce a growth curve for each individual well.

Effect of K-500 killer toxin on sensitive cell viability. The effect of K-500 killer factor on sensitive cell viability was assessed using the method of de la Pena et al. (1980). Midexponential-phase cells of S-388 were harvested by centrifugation and resuspended at a density of $3 \times 10^{7}$ cells $\mathrm{ml}^{-1}$ in a concentrated toxin solution. Over a period of $64 \mathrm{~h}$ at $18^{\circ} \mathrm{C}$, samples were removed and the number of viable cells determined by colony-forming activity on SDA plates following a $10^{5}$ dilution of the cell suspensions. The percentage of viable cells remaining in the suspension was measured by comparison with c.f.u. from a toxin-free control. Toxin binding to sensitive cells was assessed by measurement of the killer activity remaining in the supernatant after removal of cells by centrifugation (11600 $\mathrm{g}$ for $2 \mathrm{~min}$ ). The degree of toxin binding was expressed as a percentage of the initial killer activity in the preparation.

\section{RESULTS AND DISCUSSION}

\section{Determination of killer character}

An investigation was conducted to identify important killer strains among certain yeast species, including the spore-forming ascomycetes (Pichia, Schizosaccharomyces, Saccharomyces, Kluyveromyces, Williopsis and Debaryomyces) and the asporogenous yeasts (Candida and Phaffia). The potential killers were tested against several strains of $S$. cerevisiae (Philliskirk \& Young, 1975; Pfeiffer \& Radler, 1982), C. glabrata (Young \& Yagui, 1978) and against clinical isolates of Candida from vaginal swabs.

Twenty-one killers were found among the 24 strains tested and Table 1 highlights several of the killer-sensitive relationships observed. Significantly, the killer trait ap- peared to be non-specific to any one particular genus or species with killer yeasts being found in six of the eight genera tested. Strains of the genera Pichia and Williopsis showed a broad range of activity against all the indicator strains. A high incidence of killer yeasts in these genera (formerly taxonomically defied as Hansenula, Kreger van Rij, 1984; Kurtzman, 1984) has previously been reported (Philliskirk \& Young, 1975; Kazantseva \& Zimina, 1989; Michalcakova et al., 1993). It was apparent that not all strains of the same species produced the same patterns of activity and such diversity of action suggests that the toxins produced by each may be biochemically distinct from one another. Alternatively, it may be possible that multiple toxins are produced by a single yeast strain in response to being challenged by different sensitive strains (O'Leary; 1988). S. cerevisiae yeasts showed signs of interspecific killing but a weak response against Candida strains was observed. None of the sensitive strains tested were completely resistant to all of the killer strains; however, a vaginal yeast isolate, $21408 \mathrm{~J}$, showed least susceptibility to their action. The selection of the putative sensitive strains holds great significance for the identification of killer activity. An increase in the number used, and representatives of different species and genera, would undoubtedly lead to a variation in the killersensitive relationship seen. $W$. mrakii $\mathrm{K}-500$ consistently showed the strongest interstrain lethality and most extensive anti-Candida activity. As a consequence this killer yeast was selected to further investigate toxin production and toxin action against sensitive yeast strains.

\section{Anti-Candida activity of $\boldsymbol{W}$. mrakii K-500}

Clinical isolates of Candida were used to further assess the potential of $W$. mrakii $\mathrm{K}-500$ and its killer toxin as antifungal agents against pathogenic yeast strains. An initial screening of the activity of the K-500 killer yeast against a small number of isolates, from vaginal and nasal swabs, lung and tracheal aspirates and from blood, suggested a possible relationship between the sensitivity of the isolates and their physiological niche. Microtitre assays (Hodgson, 1993) revealed that the toxin was more active against the lung and tracheal aspirates (45-70\% reduction in growth) than nasal, blood and vaginal isolates (10-25\% reduction in growth). This implied an inherent genetic variation and adaptation amongst the opportunistic pathogenic flora found in the body. A more extensive screening was performed to investigate this hypothesis further.

The response of 51 clinical yeast isolates to the action of $\mathrm{K}-500$ killer toxin in microtitre bioassays is summarized in Table 2. The results confirmed that the majority of the vaginal isolates were relatively resistant to toxin action, 11 of the 17 showing less than $33 \%$ reduction in their growth. All lung and tracheal isolates tested, however, were susceptible to the killer factor displaying sensitivity in a range of 34-66\% reduction in growth. Agar diffusion well bioassays confirmed these findings and the results further emphasized that no isolate was completely resistant to toxin action. The response of sputum isolates was less pronounced and broad range of sensitivity to the 
Table 1. Agar diffusion bioassay results to highlight killer yeast characteristics against selected Candida spp. and S. cerevisiae

Results are based on a qualitative assessment of clearing zones and methylene blue staining of dead cells in the agar diffusion bioassay described in Methods. - , No killer activity; + to +++++ , trace to extensive killer activity

\begin{tabular}{|c|c|c|c|c|c|}
\hline \multirow{3}{*}{ Killer yeast strains } & \multicolumn{5}{|c|}{ Sensitive yeast strains } \\
\hline & \multirow{2}{*}{$\frac{\text { C. glabrata }}{\text { NCYC } 388}$} & \multicolumn{2}{|c|}{ Clinical Candida isolates* } & \multicolumn{2}{|c|}{ S. cerevisiae } \\
\hline & & 214392 & 21408J & NCYC 1006 & S381 \\
\hline $\begin{array}{c}\text { Picbia anomala } \\
\text { NCYC } 432\end{array}$ & +++ & ++ & - & ++ & ++++ \\
\hline $\begin{array}{c}\text { Pichia anomala } \\
\text { NCYC } 750\end{array}$ & ++ & - & - & ++ & + \\
\hline W. mrakii LKB 169 & ++++ & + & - & +++ & +++ \\
\hline W. mrakii NCYC 500 & ++++ & +++ & ++ & +++++ & ++++ \\
\hline S. cerevisiae $\mathrm{K} 28$ & ++ & + & + & - & + \\
\hline S. cerevisiae NCYC 761 & - & - & - & - & + \\
\hline $\begin{array}{l}\text { Kluyveromyces } \\
\text { marxianus NCYC } 587\end{array}$ & + & + & - & + & ++ \\
\hline
\end{tabular}

* These cultures were vaginal swab isolates obtained from Ninewells Hospital and Medical School, Dundee, UK.

Table 2. Anti-Candida activity of K-500 killer toxin against yeast isolates from clinical specimens

Results are accumulated from a series of microtitre plate bioassays.

\begin{tabular}{|c|c|c|c|c|}
\hline \multirow[t]{2}{*}{$\begin{array}{l}\text { Clinical yeast } \\
\text { isolates }\end{array}$} & \multirow{2}{*}{$\begin{array}{c}\text { No. of } \\
\text { isolates } \\
\text { tested }\end{array}$} & \multicolumn{3}{|c|}{$\begin{array}{l}\text { No. of isolates showing \% } \\
\text { reduction in growth }\end{array}$} \\
\hline & & $0-33 \%$ & $34-66 \%$ & $67-100 \%$ \\
\hline $\begin{array}{l}\text { Lung and tracheal } \\
\text { aspirates }\end{array}$ & 5 & 0 & 5 & 0 \\
\hline Vaginal* & 17 & 11 & 4 & 2 \\
\hline Sputum & 15 & 6 & 2 & 7 \\
\hline Oralt & 7 & 2 & 4 & 1 \\
\hline Blood $\ddagger$ & 2 & 1 & 1 & 0 \\
\hline Oesophageal & 1 & 0 & 1 & 0 \\
\hline Ear & 1 & 0 & 1 & 0 \\
\hline Urethral & 1 & 0 & 0 & 1 \\
\hline Abdominal & 1 & 0 & 0 & 1 \\
\hline Urine & 1 & 0 & 0 & 1 \\
\hline
\end{tabular}

* These include both vaginal swabs and endocervical smears.

$\dagger$ These include both mouth and throat swabs.

$\ddagger$ These isolates were previously identified as $C$. pseudotropicalis and $C$. parapsilosis.

killer factor was observed in both assays. Oral isolates (from throat and mouth swabs) and two isolates from blood, previously identified as Candida pseudotropicalis and Candida parapsilosis, displayed a weak sensitivity to K-500 toxin with only two specimens showing a greater than $50 \%$ reduction in growth. Single isolates from oesophageal, ear and urethral swabs, abdominal drain sites and urine were available for assay and the results from the microtitre assay closely paralleled those from the agar well bioassay. Similiar patterns of sensitivity were apparent between the initial and expanded screens, but with an increase in the number of isolates tested, the relationship between their susceptibility and physiological niche became less pronounced. It was thought possible that the 
sensitivity of isolates to toxin action was a species-specific phenomenon. The cultures obtained from a local hospital were classified only as belonging to the genus Candida, with the exception of those isolated from blood, which were identified as $C$. pseudotropicalis and $C$. parapsilosis. Seventy-four percent of the clinical samples were subsequently identified using a commercial diagnostic kit (Microring YT) and of these $86 \%$ were found to be strains of $C$. albicans. Therefore, a differential sensitivity to the action of K-500 killer toxin was found among isolates of the same species, some strains being resistant to toxin action whereas growth of others was completely inhibited. Grouping of the isolates with respect to their response to K-500 could therefore be used to biotype clinical samples of Candida, as previously reported by Polonelli et al. (1983), and possibly other opportunistic yeasts including C. glabrata, C. parapsilosis and Cryptococcus neoformans (Morace et al., 1984; Caprilli et al., 1985). The patterns of sensitivity observed were likely to be as a result of a number of factors including: site of isolation (which undoubtedly influenced species and strain type found); micro-environmental conditions within the niche (which may have induced morphological changes in the isolates); the status of the individual (which may have influenced isolate type); and cell wall characteristics. A combination of these factors could affect the interaction between the toxin molecules and their cell surface receptors and the type and number of receptors available may differ between isolates.

\section{K-500 killer yeast growth and toxin production}

The production of toxin by the killer yeast K-500 in complex (YEPD), synthetic (SLM) and a minimal medium (YNBGS) was compared. Each medium supported the growth of the killer yeast and accumulation of the killer factor in the extracellular medium followed cell growth (Fig. 1). The measured killing activity increased with cell titre during the exponential phase of growth and levelled off as cells reached their stationary phase. W. mrakii has simple nutritional requirements (Barnett et al., 1983), so good cell growth in the chemically defined medium was not unexpected. The presence of magnesium sulphate in the medium was thought to potentiate toxin production (Ohta et al., 1984) although this effect may have been secondary to improved cell growth and biomass accumulation. Ammonium sulphate was added in an attempt to stimulate protein synthesis by promotion of glutamic acid availability as a basic intermediate of amino acid precursors (Grafe, 1982) and to stabilize any killer factor produced (Ouchi et al., 1978). The use of a minimal medium in the absence of extraneous polypeptides for toxin production was preferred because it would potentially yield material with a high specific activity and would, therefore, allow an integration of fermentation with downstream purification of K-500 toxin. The minimal medium YNBGS was, therefore, selected as the growth medium for further studies, despite a slight reduction in toxin activity in comparison to that detected in cell-free extracts from cultures grown in YEPD.

To facilitate the production of workable titres of active

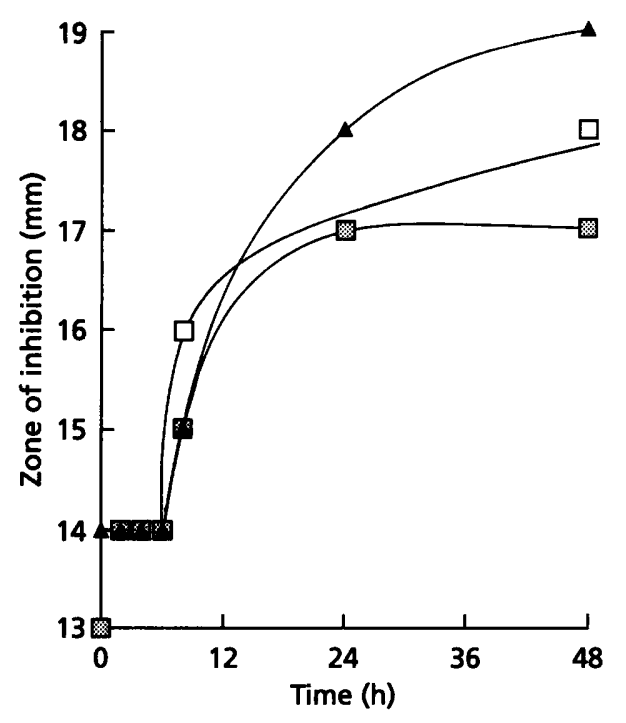

Fig. 1. Toxin production by killer yeast K-500 in different growth media. Toxin activity of K-500 cell-free supernatants was monitored using the agar diffusion bioassay and results plotted represent the mean zones of inhibition of replicate wells. $\triangle$, YEPD medium; $\square$, YNBGS medium; 용, SLM medium.

killer factor under static culture conditions it was necessary to grow the yeast over extended periods of time. In an attempt to reduce fermentation times a study was conducted to investigate the effect of agitation and oxygenation on toxin production and activity. The results of this study demonstrated that $W$. mrakii $\mathrm{K}-500$ was ' microaerophilic' in its oxygen requirements and gentle agitation of the culture created sufficient oxygen transfer for growth and secretion of the killer factor into the extracellular medium. Static, anaerobic fermentations supported cell growth of K-500, although there was a reduction in the maximum growth achieved and an increase in mean generation time of cells in exponential phase (to $10 \cdot 4 \mathrm{~h}$ ). The activity of the killer factor produced was also reduced. Direct aeration of the culture resulted in shortened mean generation times $(4.0 \mathrm{~h})$ but there was a reduction in the final cell numbers as stationary phase was reached. The maximum toxin activity achieved was only $50 \%$ of that in the agitated systems and as fermentation progressed toxin activity was lost. These observations could not be explained by a reduction in cell biomass alone, but suggested that the killer factor of K-500 became unstable in the presence of high levels of oxygen. Oxidation of amino acids in the primary structure of the protein may have led to aberrations in the folding and tertiary structure of the toxin, or an increase in the production of extracellular proteases caused the proteolytic breakdown of toxin molecules.

In short, toxin production in the killer yeast $\mathrm{K}-500$ was a growth-related response in minimal medium (YNBGS) and the killer factor was produced as cells progressed from late-exponential to early-stationary phase. Protein levels in the extracellular medium mirrored toxin production and an agitated system led to the highest titres of killer factor. 


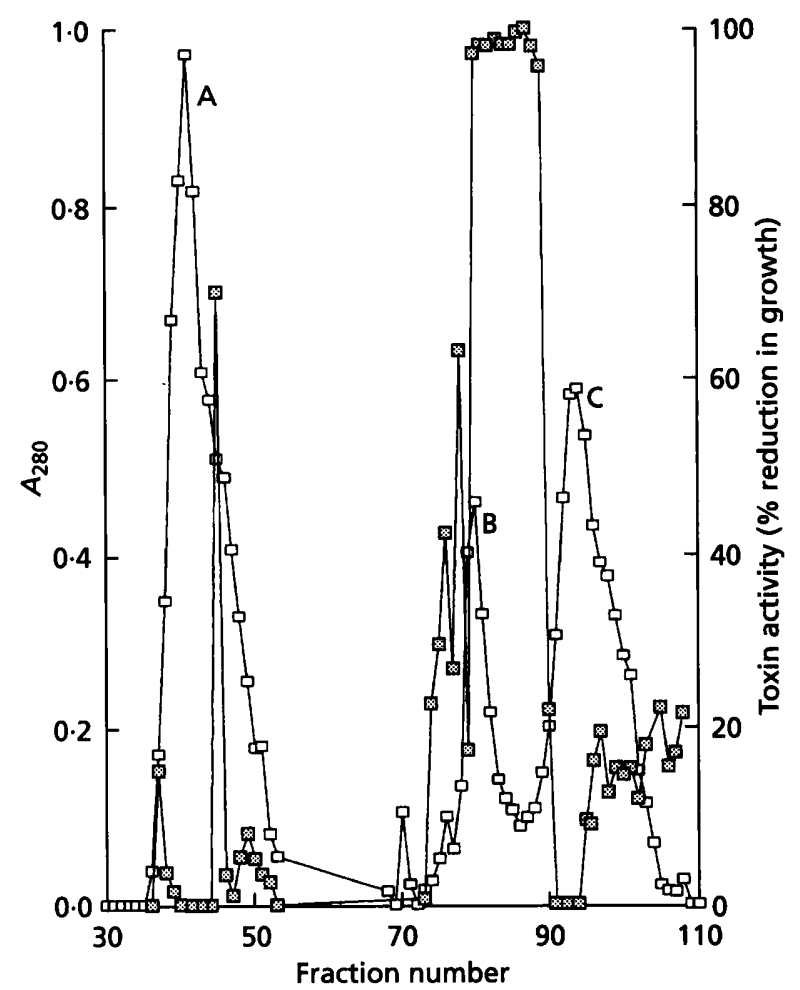

Fig. 2. Elution profile of K-500 killer toxin through a Sephadex G25 column. A crude preparation of K-500 (276 mg dry wt ml-1) was eluted with distilled water and the protein profile $(\square)$ of $5 \mathrm{ml}$ fractions measured at $280 \mathrm{~nm}$. Toxin activity (圆) was measured against C. glabrata NCYC 388 using a microtitre plate assay.

\section{Characterization and partial purification of K-500 killer toxin}

Studies were conducted to characterize the killer factor of $\mathrm{K}-500$ in terms of its biochemical properties and attempts were made to purify the killer factor using gel-filtration chromatography. It was found that the killer toxin was stable for up to $24 \mathrm{~h}$ at $4{ }^{\circ} \mathrm{C}$; however, its inherent stability was reduced as incubation temperatures were increased. For example, over the same time period, $80 \%$ of the toxin activity remained, but this was reduced to $5 \%$ at a temperature of $30^{\circ} \mathrm{C}$. At $37^{\circ} \mathrm{C}$ toxin activity was completely lost between 7 and $24 \mathrm{~h}$ and the killer factor was readily inactivated at temperatures exceeding $50^{\circ} \mathrm{C}$, showing no resistance to high temperature treatment. Using a microtitre assay of toxin activity it was found that the killer toxin was stable between $\mathrm{pH} 2.4$ and 4.0 over a period of $18 \mathrm{~h}$. The killer toxin was, however, readily inactivated at $\mathrm{pH}$ values above this. A previous report by Ashida et al. (1983) stated that the killer toxin produced by $W$. mrakii LKB 169 was stable to boiling at $100{ }^{\circ} \mathrm{C}$ for 3 min when maintained at $\mathrm{pH} 4.0$ and was stable over the range $\mathrm{pH} 2 \cdot 0-11 \cdot 0$. Results from this study, therefore, further distinguished K-500 killer toxin from that produced by another strain of $W$. mrakii, LKB 169 .

A concentrated preparation of K-500 crude toxin was applied to a column of G-25 Sephadex and eluted with



Fig. 3. Elution profile of partially purified K-500 killer toxin through a Biogel P2 column. Active toxin fractions (nos 80-89) from the Sephadex G25 column separation (Fig. 2) were pooled and concentrated 40 -fold. An aliquot $(75 \mu \mathrm{l})$ was applied to the Biogel column and eluted with distilled water. Protein content $(\square)$ was measured at $280 \mathrm{~nm}$ and toxin activity (圆) was measured against C. glabrata NCYC 388 using a microtitre plate assay.

distilled water. The elution profile and toxin activity measured in each fraction is shown in Fig. 2. Protein fraction A, large molecular mass material eluted at the void volume, possessed no killer activity. Toxin activity was, however, detected in fractions 80-89. It did not appear to be associated directly with a protein peak, but rather the area between the eluted doublet $B$ and $C$. This was explained by the fact that the absorption maximum $\left(\lambda_{\max }\right)$ of the active fractions was found to be $257 \mathrm{~nm}$, with very little absorption at $280 \mathrm{~nm}$. If the molecular mass of the active toxin molecule was small, it would not be unusual for the larger residues tryptophan and tyrosine, responsible for absorption maxima at $280 \mathrm{~nm}$, to be absent, hence the reduced $\lambda_{\max }$. Proteins eluted at the void volume showed no toxin activity and the active component of the preparations was separated on the column, which suggested that the relative molecular mass, hitherto assumed to be a minimum of $10 \mathrm{kDa}$, may have been as low as $5 \mathrm{kDa}$. The active fractions from the latter separation were pooled and concentrated by freeze-drying and applied to a P2 biogel column (fractional range $1-1.8 \mathrm{kDa}$ ) to further confirm the active component of the killer toxin as a small peptide (Fig. 3). The two protein 


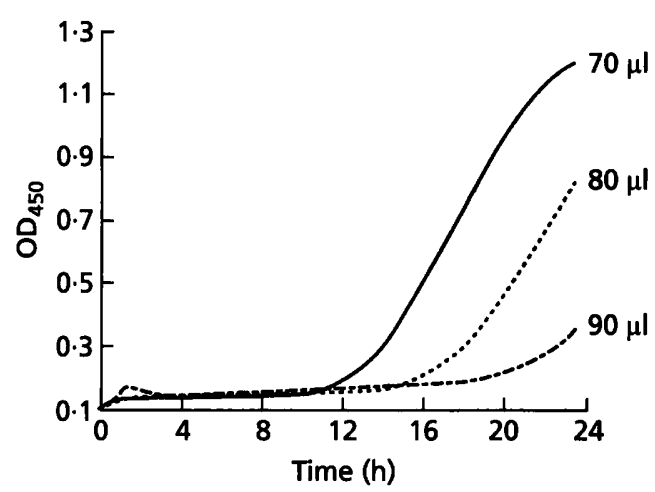

Fig. 4. Influence of K-500 killer toxin titres on the growth kinetics of C. albicans 2402E. Growth of the sensitive yeast was monitored over a $24 \mathrm{~h}$ period using an automatic spectrophotometer.

peaks $A$ and $B$ eluted at the void volume of the column displayed killer activity, which suggested that the active component possessed a minimum molecular mass of $1.8 \mathrm{kDa}$. This is significantly smaller than for any other yeast killer toxin polypeptide previously reported. The $\mathrm{K} 1$ killer toxin of $S$. cerevisiae has a molecular mass of $20 \mathrm{kDa}$ (Zhu et al., 1987), the glycoprotein toxin of $P$. anomala, $83 \mathrm{kDa}$ (Sawant et al., 1989), and P. kluyveri, $19 \mathrm{kDa}$ (Middelbeek et al., 1979). However, the smallest toxins to date are produced by yeast of the same genus: W. mrakii LKB 169 produces a toxin of $10.7 \mathrm{kDa}$ and Williopsis saturnus one of $9 \cdot 5 \mathrm{kDa}$ (Yamamoto et al., 1986a; Kimura et al., 1993).

\section{Mode of action of K-500 killer toxin against sensitive yeasts}

The mode of action and lethal effects exerted by yeast killer toxins on sensitive cells have been investigated for only a few toxins. Notably, the K1 killer toxin of $S$. cerevisiae is characterized by leakage of $\mathrm{K}^{+}$and ATP and disruption of macromolecular synthesis (Bussey \& Sherman, 1973; Skipper \& Bussey, 1977) whilst the K. lactis toxin is thought to arrest cell proliferation in the G1 phase of the cell cycle (White et al., 1989). Previous studies with $W$. mrakii LKB 169 suggested that this killer yeast produced a toxic protein which preferentially inhibited (1,3)- $\beta$-glucan synthesis (Yamamoto et al., 1986b).

Contrary to several reports on other killer yeasts (Woods, 1966; Pietras \& Bruenn, 1976; Tipper \& Bostian, 1984), the killer toxin of K-500 was found to be more active against stationary phase cells than cells in an exponential phase of growth. If the killer factor, in common with other killer yeasts, acted at the level of the cell envelope it is possible that fewer receptors were available for interaction with toxin molecules in immature exponential cells, or that receptors had less affinity for the toxin during active growth. The effect of K-500 killer toxin on the growth kinetics of several strains of $C$. albicans was

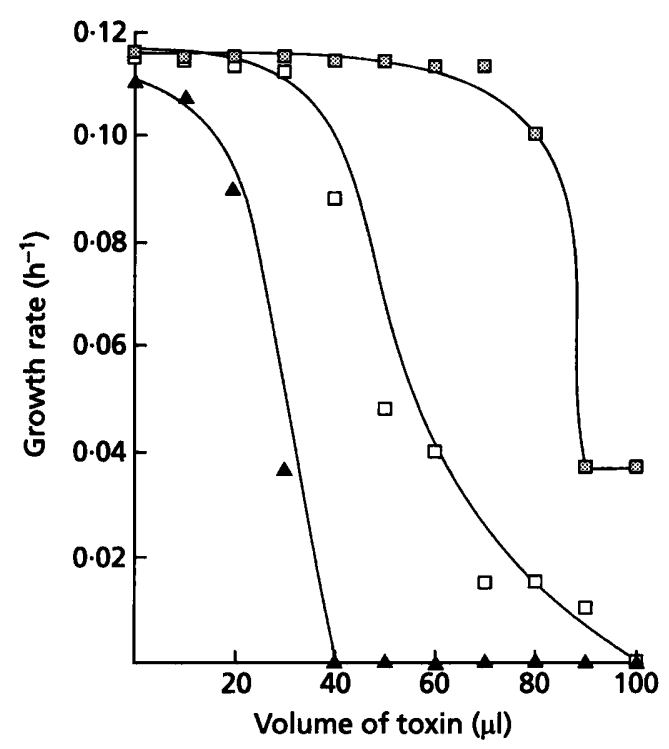

Fig. 5. Influence of K-500 killer toxin titres on growth rates of sensitive strains of $C$. albicans, 2402E (圈), 2005E ( $\square$ ) and C316 (A).

monitored in an automated spectrophotometer over a period of $24 \mathrm{~h}$. When cells were incubated with critical volumes of toxin there was a reduction, or no further increase, in the turbidity of the cultures. Fig. 4 shows the effect of increasing volumes of K-500 killer factor on Candida strain 2402E. The killer toxin maintained cells in lag phase and prevented, or inhibited, their progression into an exponential phase of growth and an increase in cell numbers. The killer factor may, like the $K$. lactis toxin, cause an arrest early in the cell cycle thereby preventing cells from enlarging and reaching a critical size necessary for continued growth and cell division (White et al., 1989). From this data, it was determined that sub-critical levels of toxin resulted in a slowing of growth rates in all strains tested. However, as Fig. 5 shows, the killer factor expressed a differential killing action against each. The observed dose-response of the sensitive strains to the effects of the killer toxin supported the hypothesis that a critical number of toxin molecules were associated with, or bound to, sensitive cells to elicit a lethal or inhibitory event. The differential response between different strains of $C$. albicans may be a result of different numbers of receptors being available on sensitive cell walls for toxin interaction.

According to de la Pena et al. (1980) killer toxin from a strain of $S$. cerevisiae bound to sensitive cells immediately after addition. However, $50 \%$ mortality resulted only after $40 \mathrm{~min}$. A lag phase before the killer toxin action is exerted has previously been reported (Kotani et al., 1977; Skipper \& Bussey, 1977) but de la Pena et al. (1980) later described an immediate effect on the co-transport of amino acids and $\mathrm{H}^{+}$. Results of the present studies demonstrate that K-500 killer toxin produced an early effect on sensitive cell viability following toxin binding 


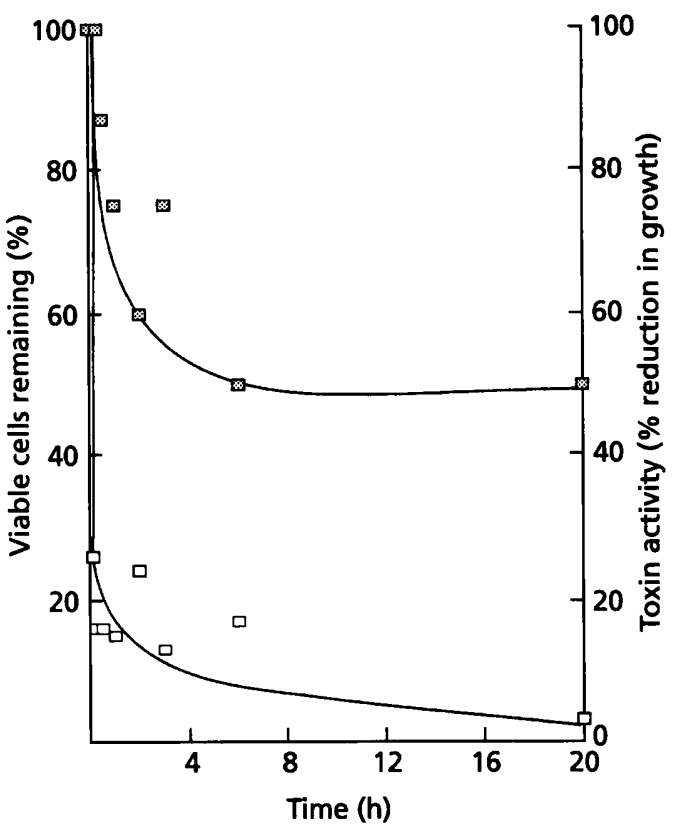

Fig. 6. Influence of K-500 killer toxin on viability of C. glabrata NCYC 388. Cells of the sensitive yeast were incubated with crude preparations of K-500 toxin and cell viability $(\square)$ assessed at intervals by colony forming activity on SDA plates. Toxin binding was assessed by measuring residual toxin activity (圈) using a microtitre plate assay.

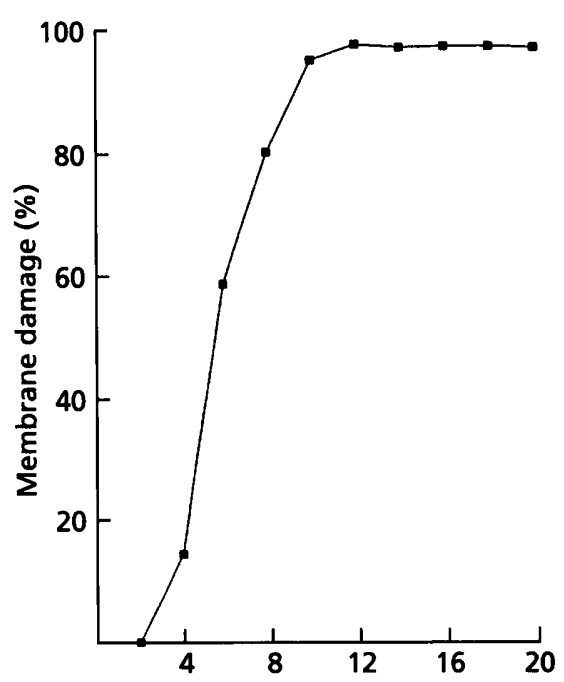

Toxin protein concentration $\left(\mu \mathrm{g} \mathrm{ml}^{-1}\right)$

Fig. 7. Membrane damage in C. albicans caused by K-500 killer toxin. Sensitive cells of $C$ albicans 2005E were loaded with 2amino $\left[{ }^{14} \mathrm{C}\right]$ isobutyric acid (see Methods) and the extent of membrane damage produced was expressed as the amount of radioactivity released from pre-loaded cells after killer toxin treatment with respect to a non-treated control.

(Fig. 6) and that no lag period was observed. A minimal amount of toxin binding occurred within $15 \mathrm{~min}$; however, this resulted in a $75 \%$ loss in the number of viable cells remaining. The initial response was followed by an increase $(3-65 \%)$ in toxin binding over a $2 \mathrm{~h}$ period but this only produced a further $10 \%$ loss in viable cells. This suggested that the toxin molecules were possibly binding to dead, as well as live cells and that the ultrastructure of the dead cells remained intact following toxin action allowing continued binding of the toxin to saturation.

The exact mechanism by which the killer toxin of K-500 exerts its lethal action on sensitive Candida strains remains unclear. However, there is some evidence to suggest that the killer toxin produced channels in the sensitive cell promoting the loss of ions and, ultimately, leading to cell death (Hodgson, 1993). A membrane damage assay (see Methods) demonstrated that the K-500 toxin did in fact disrupt sensitive yeast membrane permeability by causing the release of a radioactively labelled amino acid from preloaded cells (Fig. 7). This suggested that K-500 killer toxin acted in a similar manner to the $\mathrm{K} 1$ killer toxin of $S$. cerevisiae (Martinac et al., 1990) and the toxin of Pichia kluyveri (Kagan, 1983). Purification of the killer factor from $W$. mrakii $\mathrm{K}-500$ to homogeneity may allow more complete characterization of the bioactive peptide(s) thus contributing to the understanding and synthesis of a novel antifungal agent with the potential for therapy of Candida infections.

\section{ACKNOWLEDGEMENTS}

We thank the technical staff of the Molecular and Life Sciences Department. The work was supported by the Biotechnology and Biological Sciences Research Council and Glaxo Group Research, Greenford, Middlesex, UK.

\section{REFERENCES}

Ashida, S., Shimazaki, T., Kitano, K. \& Hara, S. (1983). New killer toxin of Hansenula mrakii. Agric Biol Chem 47, 2953-2955.

Barnett, J. A., Payne, R. W. \& Yarrow, D. (1983). Yeasts: Characteristics and Identification. Cambridge: Cambridge University Press.

Boone, C., Sdicu, A.-M., Wagner, J., Degre, R., Sanchez, C. \& Bussey, H. (1990). Integration of the yeast K1 killer toxin gene into the genome of marked wine yeasts and its effect on vinification. $\mathrm{Am}$ $J$ Enol Vitic 41, 37-42.

Bortol, A., Nudel, C., Fraile, E., de Torres, R., Giuletti, A., Spencer, J. F. T. \& Spencer, D. (1986). Isolation of the yeast with killer activity and its breeding with an industrial brewing strain by protoplast fusion. Appl Microbiol Biotechnol 24, 414-416.

Bussey, H. (1972). Effects of the yeast killer factor on sensitive cells. Nature New Biol 235, 73-75.

Bussey, H. (1991). K1 killer toxin, a pore-forming protein from yeast. Mol Microbiol 5, 2339-2343.

Bussey, H. \& Sherman, D. (1973). Yeast killer factor: ATP leakage and coordinate inhibition of macromolecular synthesis in sensitive cells. Biochim Biophys Acta 298, 868-875.

Caprilli, F., Prignano, G., Latella, C. \& Tavarozzi, S. (1985). Amplification of the killer systems for differentiation of Candida albicans strains. Mykosen 28, 569-573.

Chan, S. J., Patzelt, C., Duguid, J. R., Quinn, P., Labrecque, A., Noyes, B., Keim, P., Henrikson, R. L. \& Steiner, D. F. (1979). Precursor in the biosynthesis of insulin and other peptide hormones. 
In From Gene to Protein, pp. 361-402. Edited by T. R. Russel, K. Brew, H. Faber \& J. Schultz. New York: Academic Press.

Dignard, D., Whiteway, M., Germain, D., Tessier, D. \& Thomas, D. Y. (1991). Expression in yeast of a cDNA copy of the K2 killer toxin gene. Mol \& Gen Genet 227, 127-136.

Grafe, U. (1982). Relevance of microbial nitrogen metabolism to production of secondary metabolites. In Overproduction of Microbial Products, pp. 63-75. Edited by V. Vrumphanzl, B. Sikyta \& Z. Venek. London: Academic Press.

Hodgson, V. J. (1993). Anti-Candida activity of killer toxins from the yeast Williopsis mrakii. $\mathrm{PhD}$ thesis, Dundee Institute of Technology, Scotland, UK.

Kagan, B. L. (1983). Mode of action of yeast killer toxins: channel formation in lipid bilayer membranes. Nature 302, 709-711.

Kandel, J. S. (1988). Killer systems in pathogenic fungi. In Viruses of Fungi and Simple Eukaryotes, pp. 243-263. Edited by Y. Koltin \& M. Leibowitz. New York: Marcel Dekker.

Kazantseva, D. I. \& Zimina, M. S. (1989). Yeast killer strains with a broad spectrum of activity: search of collection strains and preliminary identification. Mikrobiologiya 58, 230-235.

Kimura, T., Kitamoto, Y., Matsuoka, K., Nakamura, K., limura, Y. \& Kito, Y. (1993). Isolation and nucleotide sequences of the genes encoding killer toxins from Hansenula mrakii and $H$. saturnus. Gene 137, 265-270.

Kotani, H., Shinmyo, A. \& Enatsu, T. (1977). Killer toxin for sake yeast: properties and effects of adenosine 5-phosphate and calcium ion on killing action. J Bacteriol 129, 640-650.

Kreger van Rij, N. W. (1984). The Yeasts: a Taxonomic Study, 3rd edn. Amsterdam: Elsevier Science Publications.

Kurtzman, C. P. (1984). Synonomy of the yeast genera Hansenula and Pichia demonstrated through comparisons of deoxyribonucleic acid relatedness. Antonie Leeunenboek 50, 209-217.

Makower, M. \& Bevan, E. A. (1963). The physiological basis of killer character in yeast. In Genetics Today, vol. 1. Proceedings of the XI International Congress on Genetics, pp. 202-203. Edited by S. J. Goerts. The Hague: MacMillan.

Martinac, B., Zhu, H., Kubalski, A., Zhou, X., Culbertson, M., Bussey, H. \& Kung, C. (1990). Yeast K1 killer toxin forms ion channels in sensitive yeast sphaeroplasts and in artificial liposomes. Proc Natl Acad Sci US A 87, 6228-6232.

Meinhardt, F., Kempen, F., Kaemper, J. \& Esser, K. (1990). Linear plasmids among eukaryotes: fundamentals and application. Curr Genet 17, 89-95.

Michalcakova, S., Sulo, P. \& Slavikova, E. (1993). Killer yeast of Kluyveromyces and Hansenula genera with potential application in fermentation and therapy. Acta Biotechnol 13, 341-350.

Middelbeek, E. J., Hermans, J. M. H. \& Stumm, C. (1979). Production, purification and properties of a Picbia kluyveri killer toxin. Antonie Leeunenboek 45, 437-450.

Morace, G., Archibussi, C., Sesito, M. \& Polonelli, L. (1984). Strain differentiation of pathogenic yeasts by the killer system. Mycopathologia 84, 81-85.

Morace, G., Manzara, S., Dettori, G., Fanti, F., Conti, S., Campana, L., Polonelli, L. \& Chezzi, C. (1989). Biotyping of bacterial isolates using the killer system. Eur J Epidemiol 5, 303-310.

Naumova, T. I. \& Naumov, G. I. (1973). Comparative genetics of yeast. XII. Study of antagonistic interrelations in Saccharomyces yeast. Genetika 9, 85-90.

Ohta, Y., Tsukada, V. \& Sugimeri, T. (1984). Production, purification and characterisation of $\mathrm{HY} 1$, an anti-yeast substance, produced by Hansenula saturnus. Agric Biol Chem 48, 903-908.
O'Leary, E. (1988). Secretion of multiple killer toxins by Williopsis mrakii. Abstracts of the Annual Meeting of the American Society for Microbiology F-19, 394.

Ouchi, K., Kawase, N., Nakano, S. \& Akiyama, H. (1978). Stabilisation of the yeast killer factor by glycerol. Agric Biol Chem 42, 1407-1417.

de la Pena, P., Barros, F., Gascon, S., Ramos, S. \& Lazo, P. S. (1980). Primary effects of yeast killer toxin. Biochem Biopbys Res Commun 96, 544-550.

Pfeiffer, P. \& Radler, F. (1982). Purification and characterization of the protein toxin from Saccharomyces cerevisiae strain 28. J Gen Microbiol 128, 2699-2706.

Philliskirk, G. \& Young, T. W. (1975). The occurrence of killer character in yeast of various genera. Antonie Leeuwenboek 41, 147-151.

Pietras, D. F. \& Bruenn, J. A. (1976). The molecular biology of yeast killer factor. Int J Biochem 7, 173-179.

Polonelli, L. \& Morace, G. (1986). Reevaluation of the killer phenomenon. J Clin Microbiol 24, 866-869.

Polonelli, L., Archibussi, C., Sestitio, M. \& Morace, G. (1983). Killer system: a simple method for differentiation of Candida albicans strains. J Clin Microbiol 17, 774-780.

Polonelli, L., Lorenzini, R., De Bernadis, F. \& Morace, G. (1986). Potential therapeutic effect of yeast killer toxin. Mycopathologia 96, 103-107.

Polonelli, L., Conti, S., Campani, L., Morace, G. \& Fanti, F. (1989). Yeast killer toxins and dimorphism. J Clin Microbiol 27, 1423-1425.

Sawant, A. D., Abdelal, A. T. \& Ahear, D. G. (1989). Purification and characterization of the anti-Candida toxin of Pichia anomala WC65. Antimicrob Agents Chemother 33, 48-52.

Skipper, N. \& Bussey, J. (1977). Mode of action of yeast toxins: energy requirement for Saccharomyces cerevisiae killer toxin. J Bacteriol 129, 668-677.

Somers, J. M. \& Bevan, E. A. (1969). The inheritance of killer character in yeast. Genet Res Commun 13, 71-83.

Sossin, W. S., Fisher, J. M. \& Scheller, R. H. (1989). Cellular and molecular biology of neuropeptide processing and packaging. Neuron 2, 1407-1417.

Stark, M. J. R., Boyd, A., Mileham, A. J. \& Romanos, M. A. (1990). The plasmid-encoded killer system of Kluyveromyces lactis. Yeast 6, 1-29.

Starmer, W. T., Ganter, P. F. \& Aberdeen, V. (1987). The ecological role of killer yeasts in natural communities of yeasts. Can J Microbiol 33, 783-796.

Stumm, C., Hermans, J. M. H., Middlebeek, E. J., Croes, A. F. \& De Vries, G. J. M. (1977). Killer sensitive relationships in yeasts from natural habitats. Antonie Leeuwenhoek 43, 125-128.

Tipper, D. J. \& Bostian, K. A. (1984). Double-stranded ribonucleic acid killer systems in yeasts. Microbiol Rev 48, 125-126.

Walker, G. M., MacLeod, A. M. \& Hodgson, V. J. (1995). Interactions between killer yeasts and pathogenic fungi. FEMS Microbiol Lett 127, 213-222.

White, J. H., Butler, A. R. \& Stark, M. J. R. (1989). Kluyveromyces lactis toxin does not inhibit adenylate cyclase. Nature 341, 666-668.

Woods, D. R. (1966). Studies of the nature of 'killer factor' in yeast. $\mathrm{PhD}$ thesis, University of Oxford, UK.

Woods, D. R. \& Bevan, E. A. (1968). Studies on the nature of the killer factor produced by Saccharomyces cerevisiae. Heredity 21, 121-130.

Yamamoto, T., Imai, M., Tachibana, K. \& Mayumi, M. (1986a). 
Application of monoclonal antibodies to the isolation and characteristics of a killer toxin secreted by Hansenula mrakii. FEBS Lett 195, 253-257.

Yamamoto, T., Hiratani, T., Hirata, M., Imai, K. \& Yamaguchi, H. (1986b). Killer toxin from Hansenula mrakii selectively inhibits cell wall synthesis in sensitive yeast. FEBS Lett 197, 50-54.

Young, T. W. (1982). The properties and brewing performance of brewing yeasts possessing killer character. $J$ Amer Soc Brew Chem 42, 1-4.
Young, T. W. \& Yagui, M. (1978). A comparison of the killer character in different yeasts and its classification. Antonie Leeuwenboek 44, 59-77.

Zhu, H., Bussey, H., Thomas, D. Y., Gagnon, J. \& Bell, A. W. (1987). Determination of the carboxyl termini of the $\alpha$ and $\beta$ subunits of the yeast K1 killer toxin. J Biol Cbem 262, 10728-10732.

Received 20 February 1995; accepted 19 April 1995. 